DOI 10.4467/25439561KSR.19.011.11327

\author{
AleKSANDRA PoPIŃSKA-PINDYCH (1) https://orcid.org//0000-0001-5389-0703 \\ Uniwersytet Humanistyczno-Przyrodniczy im. Jana Długosza \\ Częstochowa
}

\title{
EKUMENICZNA MISJA WILLIAMA PALMERA DO ROSJI W ŚWIETLE JEGO UWAG PO ODWIEDZENIU CERKWI ROSYJSKIEJ W LATACH 1840-1841
}

\author{
WILLIAM PALMER'S ECUMENICAL MISSION TO RUSSIA \\ IN THE LIGHT OF HIS NOTES OF A VISIT \\ TO THE RUSSIAN CHURCH IN THE YEARS 1840-1841
}

\section{Streszczenie}

William Palmer, traktarianin, absolwent Uniwersytetu Oksfordzkiego, teolog i liturgista, poświęcił życie idei pojednania Kościoła anglikańskiego z Kościołem prawosławnym. W myśl opisanej przez niego „teorii gałęzi” Kościół katolicki, anglikański i prawosławny - jak gałęzie jednego drzewa - są głęboko ze sobą zjednoczone, nie tylko historycznie przez ten sam korzeń, ale i dogmatycznie przez tę samą istotę kultu. Po uzyskaniu listów polecających od angielskich dostojników kościelnych i świeckich Sir Palmer udał się z samozwańczą misją ekumeniczną do Rosji. Samozwańczą - gdyż choć miał poparcie wielu, to jednak propagowanie idei, by odnowić więzi z Cerkwią było próbą urzeczywistnienia jego własnego marzenia życia. Uwagi po odwiedzeniu Cerkwi rosyjskiej w latach 1840-1841 są owocem jego doświadczeń, rozczarowań i zachwytów podczas tego przedsięwzięcia. Choć jego nadzieje na interkomunię i zjednoczenie szybko okazały się nie mieć szans na realizację, podczas pobytu w Rosji poznał dogłębnie zwyczaje i codzienne życie tamtejszych wiernych i kapłanów, co zostało uwiecznione na kartach jego notatnika. Artykuł ten jest próbą przybliżenia czytelnikowi tego zupełnie nieznanego w Polsce dzieła, które zredagował i wydał po śmierci Palmera sam kardynał John Newman, nie chcąc, by poświęcenie tak wyjątkowego teologa poszło w zapomnienie.

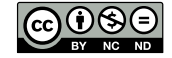




\begin{abstract}
William Palmer, a tractarian, a graduate of Oxford University, a theologian and liturgist devoted his life to the reconciliation of the Anglican Church with the Orthodox Church. According to the branches theory which he postulates, the Catholic, Anglican and Orthodox Churches - like the branches of one tree - are deeply united, not only historically - by the same root, but also dogmatically by the same essence of worship. Sir Palmer, after receiving letters of recommendation from the bishops of the Church of England and secular dignitaries, went on a self-proclaimed ecumenical mission to Russia. Notes of a Visit to the Russian Church in the Years 1840-1841 are the fruit of his adventures, disappointments and admirations he had experienced during his quest. Although his hopes for intercommunion and unification quickly proved to have no chance of fulfillment, during his stay he thoroughly learnt the customs and the routine of a daily life of the faithful and priests in Russia, which was immortalized on the pages of his notebook. This article is an attempt to familiarize the reader with this outstanding work - completely unknown in Poland, which was edited after Palmer's death by cardinal John Newman, who wanted to prevent the dedication of such an exceptional theologian from being forgotten.
\end{abstract}

Słowa kluczowe: ekumenizm, William Palmer, ruch oksfordzki, traktarianie, prawosławie

Keywords: ecumenism, William Palmer, The Oxford Movement, tractarians, the Orthodox Church

Rosja, postrzegana przez Anglików jako kraj kuszący pewnym orientalizmem, ale cywilizowany i nie skrajnie egzotyczny, stała się celem podróży mieszkańców Wysp Brytyjskich dość wcześnie, bo już za czasów cara Iwana III, choć Ernest J. Simmons, wybitny amerykański znawca rosyjskiej kultury, dowodzi, że to dopiero car Iwan Groźny otworzył Rosji „okno na Europę”. Pierwsze podróże do Rosji, po których pozostały zapiski, będące skarbnicą wiedzy na temat wzajemnych stosunków rosyjsko-angielskich, były podejmowane przez brytyjskich kupców i odkrywców (Richard Chancellor, Jerome Horsey), podróżników (Sebastian Cabot, K. Adams), niezliczonych dyplomatów, literatów i specjalistów na państwowych posadach ${ }^{1}$. Poza osobami przyjeżdzającymi do Rosji z wyżej wymienionych pobudek literatura wspomina też wybitne jednostki, których cel podróży był wręcz altruistyczny. Należy tu wymienić Johna Howarda, Anglika, który przybył do Rosji w 1781 roku z nadzieją reformy tamtejszego systemu penitencjarnego. Apelował on o rozróżnienie między karą za popełnione winy a męką. Był tak wnikliwym obserwatorem, że zauważył, iż

1 Т.Л. Лабутина, Англичане в допетровской России, Санкт-Петербург, Алетейя, 2011, ss. 7-8. 
choć za Katarzyny II nie było w Rosji kary śmierci, to niehumanitarne metody stosowane w więziennictwie rosyjskim często właśnie nią się kończyły². Żywa obecność Rosji w literaturze brytyjskiej ma zatem swoją wielowiekową historię?

Gdy William Palmer w 1840 roku wyrusza w podróż do Petersburga, nie jest zatem pionierem przecierającym szlak kolejnym pokoleniom odkrywców nowej destynacji. Jednak cel, jaki mu przyświeca, jest wyjątkowy i zasadniczo inny niż jego poprzedników - Palmer decyduje się na misję (bo tak warto patrzeć na jego podróż, biorąc pod uwagę zachowane materiały archiwalne) udowodnienia, że Kościół anglikański i Cerkiew rosyjska mogą się pojednać. Można pokusić się nawet o nazwanie go brytyjskim inicjatorem i prekursorem idei zjednoczenia obu Kościołów. Jego śladem podąży kilka lat później zafascynowany jego osobą i poglądami John Birkbeck, również oksfordzki ekumenista. I choć dokonania na polu dialogu ekumenicznego Johna Birkbecka można uznać za znacznie większe niż jego poprzednika ${ }^{4}$, to nie da się zaprzeczyć, że to właśnie William Palmer jako pierwszy absolwent Oksfordu rozpalił nadzieję anglokatolików $w^{5}$ na unię z Cerkwią rosyjską, a Birkbeck był jedynie kontynuatorem wyznaczonego przez niego kierunku.

Przyjęcie na soborze w Konstantynopolu nicejsko-konstantynopolitańskiego zmienionego wyznania wiary wraz ze słynnym filioque jest często przez angielskich historyków Kościoła wskazywane jako przyczyna rozpadu i moment odłączenia się Kościoła wschodniego, który opowiedział się po stronie czystości Tradycji, na której straży zwierzchnicy prawosławni stoją po dziś dzieńn ${ }^{6}$. W opinii prawosławnych zarówno łacinnicy, jak i protestanci dokonali aktu apostazji i pojednanie Kościołów nie jest możliwe ${ }^{7}$. Podejmujący dialog ekumeniczny dostojnicy kościelni i teologowie zachodni zdają się o tej postawie Cerkwi zapominać lub ją lekceważyć. William Palmer i jego Uwagi po odwiedzeniu Cerkwi rosyjskiej w latach 1840-1841 w doskonały sposób ilustrują problemy ze zrozumieniem stanowiska Kościoła prawo-

2 B. Pindus, „Don Kichot w zniszczonym fraku”, czyli o heroizmie doktora Friedricha Haassa, „Kultura Słowian. Rocznik Komisji Kultury Słowian PAU” 2018, t. XIV, s. 341.

3 Warto nadmienić, że literatura brytyjska może się chlubić wieloma obszernymi pozycjami na temat życia w Rosji, jak np. zapiski z podróży Jerome’a Horsey'a, zredagowane przez E.A. Bonda: Russia at the Close of the Sixteenth Century, Londyn, The Hakluyt Society, 1856 czy przygotowane do druku przez samego Horsey'a: Extracts out of Sir J H's Observations in Seventeen Years Travels and Experience in Russia, [w:] Purchas his Pilgrimes, red. Samuel Purchas, Londyn, 1626.

4 W.J. Birkbeck, Birkbeck and The Russian Church, red. Athelstan Riley, New York, The MacMillan Company, 1917, s. 6. Wszystkich tłumaczeń z języka angielskiego dokonała autorka artykułu.

5 Anglokatolicyzm - termin funkcjonujący zwłaszcza na początku działalności ruchu oksfordzkiego dla określania zwolenników via media, natomiast po publikacji The Tracts for the Times powszechniej nazywano ich traktarianami.

6 W.J. Birkbeck, Birkbeck and The Russian..., op. cit., s. 262.

7 Ibidem. 
sławnego i wynikające $\mathrm{z}$ nich niepowodzenia prób ekumenicznych inicjowanych przez chrześcijan Zachodu.

Wyprawy do Rosji, organizowane $\mathrm{z}$ inicjatywy papieży z nadzieją na przyjęcie przez Moskwę ich prymatu, podejmowane we wcześniejszych wiekach, kończyły się zawsze fiaskiem. Jednak mimo to ze strony katolickiej nie zaprzestano nigdy podejmowania prób dialogu. Elita duchowieństwa katolickiego, jezuici, wielokrotnie chcieli doprowadzić do unii Cerkwi z Watykanem. Paul Shore, badacz stosunków Kościoła prawosławnego z Rzymem, opisuje je w następujący sposób:

„Relacje między jezuitami a wyznawcami prawosławia charakteryzują zarówno znaczące spotkania, jak i konflikty, i nieporozumienia. Przepaść między miejską, transnarodową i zorientowaną na wiedzę uniwersytecką kulturą jezuitów, a tradycyjną, wiejską [...] kulturą prawosławnych populacji została powiększona przez odmienne idee teologiczne i politykę wielkiej władzy. Rywalizacje etniczne i historycznie warunkowana podejrzliwość wobec katolicyzmu wśród niektórych prawosławnych również przyczyniły się do napięć"s.

Pisząc o działalności jezuitów na ziemiach rosyjskich, nie można nie wspomnieć misji Antonia Possevina SJ (1533-1611), któremu papież Grzegorz XIII powierzył w latach 1581-1585 zadanie podjęcia pertraktacji mających doprowadzić do pogodzenia walczących ze sobą Moskwy i Polski, zawarcie unii kościelnej i przymierza politycznego z Moskwą przeciw Turcji ${ }^{9}$. Possevino pozostawił wspomnienia, w których opisał wrażenia, jakie wywarli na nim moskwianie oraz ich kultura, obyczaje, a przede wszystkim religia ${ }^{10}$. W pierwszej części jego wspomnień - Moscovii - znajdujemy opis stosunków panujących w Rosji i różnic między religią prawosławną a katolicyzmem ${ }^{11}$. Misja Possevina przez całe lata była przedmiotem sporów i rozmaitych manipulacji naukowych, zwłaszcza po stronie rosyjskiej, nie wyłączając czasów socjalistycznych ${ }^{12}$. Choć Moscovia przedstawia Rosję szesnastowieczną, wiele spostrzeżeń $\mathrm{w}$ niej zawartych jest bardzo zbliżonych do tych prezentowanych przez Palmera w Uwagach, a jej autor jawi się na kartach zapisków „nie tylko

8 P. Shore, Jesuits in the Orthodox World, [w:] The [Oxford] Handbook of the Jesuits, red. I.G. Zupanov, https://www.oxfordhandbooks.com/view/10.1093/oxfordhb/9780190639631.001.0001/oxfordhb-9780190639631-e-13 [dostęp: 06.05.2019]. O jezuitach w Rosji por. także: M. Inglot, How the Jesuits Survived Their Suppression. The Society of Jesus in the Russian Empire, Philadelphia, Saint Joseph's University Press, 2015.

9 M. Inglot SJ, La Missione del Possevino nella Russia di Ivan il Terrible, [w:] "Atti e Memorie", Academia Nazionale Virgiliana di Scienze Lettere e Arti, 2014, s. 216.

10 A. Possevino, Moscovia, Warszawa, Instytut Wydawniczy PAX, 1988.

11 Ibidem.

12 S. Obirek, Antonio Possevino i jego misja do Moskwy, „Nasza Przeszłość” 1998, t. 89, s. 114. 
jako zręczny dyplomata, ale całkowicie oddany idei powszechnego zjednoczenia misjonarz"13.

Niniejszy artykuł ma na celu przedstawienie oczyma autora Uwag, Brytyjczyka, czynników, które w dużej mierze, pomimo wysiłków podejmowanych ze strony elit duchowieństwa brytyjskiego, utrudniały dialog ekumeniczny z Kościołem wschodnim. Zapiski Williama Palmera są skarbnicą wiedzy na temat opinii, postaw i zachowań ludności prawosławnej w Petersburgu w latach 1840-1841. To ponad 500 stron szczegółowych opisów rozmów, zwyczajów, pozytywnych zdumień i pogrzebanych nadziei na porozumienie. Dzieło to wnosi świeżość oglądu, gdyż jest pierwszą pozycją w literaturze wspomnieniowej pióra Brytyjczyka traktującą o Cerkwi rosyjskiej.

Urodzony 11 czerwca 1811 roku William Palmer był wszechstronnie wykształconym teologiem i liturgistą. Ukończył Worcester College i Uniwersytet w Oksfordzie i będąc osobą duchowną - diakonem - oraz intelektualistą i wykładowcą macierzystego uniwersytetu, wsparł rodzący się w murach jego alma mater ruch ekumeniczny, zwany też oksfordzkim lub traktariańskim. W latach 1833-1845 ruch ten miał na celu odnowę Kościoła anglikańskiego i przeciwstawienie się postępującej liberalizacji, relatywizmowi i racjonalizacji wiary, które narastały wśród anglikanów. Jako bezpośrednie przyczyny jego powstania można wskazać: sekularyzację Uniwersytetu Oksfordzkiego, emancypację różnowierców w Anglii, liberalizację torysów oraz erastianizm ${ }^{14}$ „rewolucyjnego parlamentu” ${ }^{15}$. W latach późniejszych ruch oksfordzki był również nazywany anglokatolicyzmem. To dość trafne określenie, gdyż członkowie Kościoła anglikańskiego, którego jedynym zbiorem dogmatów jest Trzydzieści dziewięć artykułów Elżbiety $\mathrm{I}^{16}$, interpretowali je w tak dowolny sposób, że nawet zdeklarowanym katolikom pozwalało to na bezpieczne wyznawanie swojej wiary pod sztandarem nowej struktury organizacyjnej. Wielu tradycjonalistów i konserwatystów wśród wykładowców Oksfordu uważało za swój obowiązek obronę Tradycji w anglokatolicyzmie. Gdy okazywało się to coraz trudniejsze, pojawiły się tenden-

${ }^{13}$ Ibidem, s. 120. Warto w tym miejscu nadmienić, że podczas swojej misji Possevino podjął się odpowiedzi na piśmie na antyrzymskie argumenty kupców angielskich przebywających w Moskwie. Por. O. Halecki, Od unii florenckiej do unii brzeskiej, Lublin, Instytut Europy Środkowo-Wschodniej, 1995, t. 2, s. 24.

${ }^{14}$ Erastianizm - teoria religijno-polityczna o zależności Kościoła od państwa, głosząca, że Kościół otrzymuje swą władzę od państwa oraz dopuszczająca apelację od władzy kościelnej do państwowej, https://encyklopedia.pwn.pl/haslo/erastianizm;3898376.html [dostęp: 02.05.2019].

15 P. Musiewicz, Ruch oksfordzki (1833-1845). Historia ruchu oksfordzkiego na tle nowożytnych relacji Państwo-Kościót w Anglii, Kraków, WAM, 2015, s. 6.

${ }^{16}$ Н.Ю. Сухова, У. Палмер в России, https://www.academia.edu/8683694/_William_Palmer_in_ Russia [dostęp: 03.05.2019], s. 94. 
cje szukania wspólnoty, interkomunii ${ }^{17}$ i dialogu z Kościołem prawosławnym, który z kolei uważał, że „najpilniejszym zadaniem było obronienie Kościoła wschodniego przed herezją ekumenizmu"18.

Odnowa duchowości w Kościele angielskim, ale też pojednanie z Kościołem wschodnim, były to pragnienia, którym Palmer poświęcił życie. W myśl teorii gałęzi (branches theory), którą sam opisał w szczegółach, wierzył - jak wszyscy traktarianie - że katolicyzm, anglikanizm i prawosławie to nic innego jak gałęzie jednego, świętego, powszechnego i apostolskiego Kościoła. Po latach Sergiusz Bułgakow odnajdzie wiele niejasności w owej koncepcji i będzie polemizował z takim postrzeganiem odłamów chrześcijaństwa, pisząc:

„Teoria ta prowadzi do wniosku, że tradycja Kościoła prawdziwego istnieje wszędzie, a zarazem i nigdzie, czyli sprowadza się do idei »Kościoła niewidzialnego«, rozpatrując pojęcie Kościoła w relatywizmie historycznym ${ }^{19}$. [...] Jak zrozumieć, w takim wypadku, świadomość każdego z Kościołów, że właśnie on jest Kościołem prawdziwym? Odpowiedź [...] jest jasna - takim jednym, prawdziwym Kościołem, w którym zachowała się jedność życia kościelnego, czyli jedność tradycji, jest prawosławie"20.

Pomimo takiego stanowiska Cerkwi, które jest niezmienne od czasu rozłamu, teoria gatęzi była koncepcją ekumeniczną, która dała najsilniejszą motywację Sir Palmerowi, by zgłębić i zbadać dotychczas mu nieznany odłam Kościoła, jakim było prawosławie. Rozczarowany faktem, iż jego towarzysze z ruchu oksfordzkiego pojednanie z Kościołem wschodnim rozważali jedynie teoretycznie, zaopatrzony w listy polecające od ważnych osobistości kościelnych i świata akademickiego postanowił udać się w samotną podróż do Rosji.

Jak podkreśla Jewgienij Ljut'ko, nie przybył on tam, by poznawać kraj i kulturę, a w poszukiwaniu jedności eucharystycznej z Cerkwią. Nie przyjechał też, by prosić o interkomunię, lecz z przekonaniem, że ma do niej pełne prawo. Przedstawiciele Cerkwi mieli w tej kwestii zgoła odmienne zdanie. Choć Filaret (Drozdow), metropolita moskiewski, uważany wówczas za największego teologa Kościoła rosyjskiego, był bardzo otwarty na ekumenizm, odmówił wsparcia dążeń Palmera do jedności Kościołów w imię ich „katolickości” (powszechności - A.P.-P.). Rosyjski hierarcha zdecydowanie stał na stanowisku, iż tylko całkowite przyjęcie zasad Kościoła prawosławnego (doktryny, reguł i liturgii) może sprawić, „by ktoś został dopuszczony

17 Jako interkomunię rozumiano możliwość przystępowania chrześcijan różnych Kościołów do Stołu Pańskiego po porozumieniu się z hierarchami tychże Kościołów. Taka interkomunia może istnieć tam, gdzie istnieją tak samo pojmowane sakramenty kapłaństwa i Eucharystii.

18 A. Kalomiros, Against False Union, Seattle, St. Nectarios Press, 1990, s. 101.

19 S. Bułgakow, Prawosławie, Warszawa, Formica, 1992, ss. 103-104.

${ }^{20}$ Ibidem, s. 104. 
do Komunii. Palmer zaś, posługując się teorią Kościołów-gałęzi, nie ocenił należycie przepaści dzielącej pojęcie »fałszywego kościoła« i stan całkowitej zgodności dogmatycznej, konieczny według mniemania prawosławnych do interkomunii"”21.

Odmienne od jego własnego stanowisko Cerkwi w kwestii ekumenizmu w żaden jednak sposób nie było w stanie zniechęcić Palmera do podjęcia próby dialogu. Był on tak przekonany o wielkiej wadze swojej misji, że nie poddawał się po pierwszych porażkach i szukał wsparcia oraz sojuszników nie tylko wśród duchowieństwa, ale i wpływowych myślicieli rosyjskich. Po powrocie do Oksfordu utrzymywał listowny kontakt z Aleksym Chomiakowem, który, jak świadczy korespondencja, był pod wrażeniem wiedzy i zaangażowania doskonale wykształconego Brytyjczyka. Jednak Chomiakow, podobnie jak i metropolita Filaret (Drozdow), nie porzucił w filozoficzno-teologicznych listownych dysputach ugruntowanego przekonania „o wyjątkowej wartości rosyjskiego prawosławia dla chrześcijan Kościoła zachodniego i ich kultury" oraz myśli, że ,jednym z ważniejszych zadań prawosławnych w podzielonym Kościele jest dawanie świadectwa Apostołów i Ojców, czyli zachowanie prawdziwej wiary, pozbawionej dodatków i innowacji wprowadzonych przez braci z Zachodu"22.

Wspomniany wcześniej William John Birkbeck, teolog współczesny Palmerowi, absolwent Eton i Magdalen College w Oxfordzie, zafascynowany kontaktami Zachodu z Cerkwią rosyjską, podjął się analizy korespondencji Palmera i Chomiakowa z tamtego okresu, gdyż chciał przed własną podróżą do Rosji zdobyć jak największą wiedzę na temat stanowiska Kościoła prawosławnego na temat kwestii zjednoczeniowych. Autor ten przytacza zapewnienia Chomiakowa zawarte w jednym z listów, że Kościół wschodni absolutnie nie traktuje obecnej sytuacji rozdziału Kościołów jako „tymczasowej kłótni czy różnicy zdań”, po której jest szansa powrotu do zgody, oparta na fakcie, iż oba te Kościoły głoszą jedną prawdę. Chomiakow pisał Palmerowi, że Wschód patrzy na Kościoły Zachodu jak na chorą część organizmu, która odpadła i jest pogrążona w błędzie i głębokiej herezji. A im bardziej Kościoły Zachodu dzieliły się, tworząc liczne odłamy, tym śmielej Kościół wschodni używał słowa „herezja” i utwierdzał się w słuszności własnej pozycji na straży nienaruszonej i niczym nieskażonej Tradycji Ojców ${ }^{23}$.

Należy podkreślić, że „nie tylko religijny antagonizm sprawił, że przedsięwzięcie Palmera skończyło się fiaskiem. Różnice kulturowe pomiędzy angielską a rosyj-

${ }^{21}$ J. Ljut'ko, Two Oxford Scholars and Their Relationship with the Russian Church: William Palmer and Stephen Hatherley, https://www.academia.edu/3362426/Two_Oxford_Scholars and their_relationship_with_the_Russian_Church_William_Palmer_and_Stephen_Hatherley [dostęp: 13.03.2019].

${ }^{22}$ U. Cierniak, Religia z „krainy świętych cudów”, [w:] Bizancjum - Prawosławie - Romantyzm. Tradycja wschodnia w kulturze XIX wieku, red. J. Ławski, K. Korotkich, 2004, ss. 44-45.

${ }^{23}$ W J. Birkbeck, Birkbeck and The Russian..., op. cit., s. 232. 
ską cywilizacją były zbyt znaczące i nie do pogodzenia" ${ }^{24}$. Fundamentalne założenia misji Palmera zdradzały całkowity brak znajomości realiów rosyjskich.

Robert Byron, rodak Palmera i także absolwent Oksfordu, żyjący i piszący całe stulecie później, i też ogarnięty podobnym pragnieniem zgłębienia i poznania prawdziwej Rosji, przed swoją tragiczną śmiercią napisał:

„Dla mnie, Anglika, korzystającego z wszelkich możliwych przywilejów urodzenia i możliwości, jakie daje współczesny świat, czymś nowym było spojrzenie na siebie nagle jako zarodek trującego grzyba. [...] Ten thum składa się z ludzi zamkniętych w sobie aż za bardzo. Nie dopuszcza możliwości kontaktu. [...] Intelektualiści z innych krajów wzbudzili w sobie złudną wiarę, że może istnieć pole do kompromisu. To nigdy nie będzie możliwe. Sport, zainteresowania intelektualne, poczucie humoru czy wyjątkowa życzliwość, jaką powoduje wódka, tworzą najwyżej swego rodzaju ziemię niczyją, na której chronią się stronnicy obu obozów, by zakopać swoje przekonania i odkryć, że należą do tego samego gatunku. Lecz rozejm zawsze jest tymczasowy"25.

Istotną kwestią, którą należy wspomnieć, jest też fakt, iż Palmer nie był niczyim wysłannikiem i była to jego prywatna misja. Otrzymał co prawda list polecający do Oberprokuratora Najświętszego Synodu od ambasadora angielskiego w Rosji, Lorda Clanricarde'a, oraz rekomendację od swojego przełożonego z Magdalen College (Dr. Martina Josepha Routh'a), te jednak, choć wzbudzały pewien szacunek, wywoływały również podejrzliwość strony goszczącej. Jedynym dostojnikiem, który prawdopodobieństwo takiej reakcji ze strony rosyjskiej przewidział, był arcybiskup Canterbury, Dr William Howley, który nie podpisał listu poręczającego, ponieważ „uważał, iż misja Palmera ma dużo większe szanse powodzenia bez jego podpisu, gdyż jednostka działająca na własną rękę nie wzbudzi takiego alarmu i poruszenia jak posiadająca list polecający od biskupa" ${ }^{26}$.

Przechodząc do analizy tekstu Uwag, nie można nie wspomnieć, że dzieło, do którego publikacji doprowadził kard. John Henry Newman (Palmer pozostawił mu zapiski w testamencie) jest opatrzone przez niego wstępem zawierającym laudację na temat osoby Palmera oraz podsumowanie jego misji. Kardynał Newman (uznany 13 października bieżącego roku przez papieża Franciszka za świętego Kościoła katolickiego) nie kryje oburzenia postawą Cerkwi i wspomina, że choć Palmera przyjmowano gościnnie ze względu na uwarunkowania polityczne i poparcie, jakie

\footnotetext{
${ }^{24}$ J. Ljut'ko, Two Oxford Scholars..., op. cit.

${ }_{25}$ R. Byron, Moskwa, ,Zeszyty Literackie” 2012, nr 1, ss. 128-129.

26 W. Palmer, Notes of a Visit to the Russian Church in the Years 1840-1841, red. Card. J. Newman, Londyn 1882, s. 19. Dalsze odwołania w tekście odnoszą się do tego wydania i są oznaczone w nawiasach jako (UCR) z podaniem numerów stron.
} 
otrzymał z Oksfordu, była to powierzchowna kurtuazja, a nikt nie słuchał, z czym do Rosji przybył. Pisze, iż:

„[...] brak uznania jedności naszych Kościołów był aktem odrażającej schizmy, budowaniem ołtarza przeciw ołtarzowi i świętokradztwem [...]. Motywem Williama Palmera, napędzającym decyzję o wyjeździe, była wiara w możliwość uznania przez Święty Synod jego praw do grecko-rosyjskich sakramentów, co byłoby potwierdzeniem, że anglikański chrześcijanin jest ipso facto prawosławnym" (UCR, VII).

Od samego dnia przyjazdu do Petersburga William Palmer wykorzystywał bardzo efektywnie czas pobytu w Rosji. Ludzie, z którymi debatował na tematy ekumeniczne, byli pod dużym wrażeniem jego oczytania i znajomości dyscypliny prawosławnej. Opowiadali o spotkaniu z Anglikiem szerszym kręgom znajomych, przedstawiając go jako wartego poznania i w ten sposób dzień po dniu napływały do przybysza nowe zaproszenia. Sir Palmer szukał zrozumienia i poparcia u całej rzeszy osób - od zwykłych księży, którzy udzielali mu gościny, po metropolitę moskiewskiego Filareta (Drozdowa). Nigdy nie odmówił przyjęcia zaproszenia. Nazwiska, którym poświęca najwięcej stron swoich zapisków, szczegółowo opisując debaty, to między innymi: Nikołaj Aleksandrowicz Protasow - Oberprokurator Najświętszego Synodu w latach 1836-1855; książę Aleksander Nikołajewicz Golicyn - Minister Oświaty Narodowej w latach 1816-1824, wcześniejszy Oberprokurator Najświętszego Synodu; biskup Wasilij Kutniewicz; wielebny Aleksander Iwanowicz Małow - znany petersburski kaznodzieja posługujący w soborze św. Izaaka (Исаакиевский собор); archimandryta Pustelni Troicko-Siergiejewskiej pod Sankt Petersburgiem Ignatij Brianczaninow (obecnie święty Cerkwi rosyjskiej); Walerij Waleriewicz Skripicyn - od 1842 roku Dyrektor Departamentu Spraw Duchownych Obcych Wyznań Ministerstwa Spraw Wewnętrznych, który wsławił się tym, że aktywnie zamykał katolickie klasztory w Rosji; protopop Gierasim Pietrowicz Pawski - profesor Petersburskiej Akademii Duchownej, tłumacz Biblii, egzegeta; Fiodor Fiodorowicz Sidonskij - protopop w Kazańskim Soborze, pisarz i filozof; księżna i książę Potiomkin; rektor Akademii Duchownej Wojciechowicz; księżna i książę Mieszczerscy; biskup Innokentij (Wieniaminow) - późniejszy biskup Kamczatki i Jakucji, a następnie metropolita moskiewski i kołomienski po Filarecie (Drozdowie); Konstantin Stiepanowicz Serbinowicz - od 1841 roku honorowy członek petersburskiej Akademii Nauk, pisarz, memuarysta, dyrektor Kancelarii Oberprokuratora Najświętszego Synodu (1836-1853).

Jeżeli tylko znajomość języka na to pozwalała, Palmer nie tracił okazji do rozmowy na tematy ekumeniczne z żadną napotkaną osobą. Głównie posługiwano się francuskim, zdarzało się, że rozmówcy władali angielskim, a duchowni czasem biegle łaciną. Do najczęstszych tematów poruszanych podczas dyskusji należały 
sakramenty, kwestia filioque i Ducha Świętego oraz warunki interkomunii. W liście do Nikołaja Aleksandrowicza Protasowa, Oberprokuratora Najświętszego Synodu, Palmer pisze:

„[...] przybyłem do diecezji rosyjskich biskupów i będąc tu, uznaję ich jurysdykcję i Kościół tutejszy jako jedyny prawdziwy i prawomocny. Nie przybyłem jako odszczepieniec czy heretyk, chcący zostać członkiem Kościoła Boga w Rosji, ale będąc katolickim ortodoksyjnym chrześcijaninem Kościoła apostolskiego, oczekuję od prawowitych, kanonicznie ustanowionych biskupów, w jakimkolwiek kraju będę, od każdego z nich w jego własnej diecezji - wzajemnego prawa do komunii” (UCR, 129).

Należy w tym miejscu jasno podkreślić, że między Kościołem anglokatolickim, reprezentowanym przez Palmera, a Cerkwią nie było niezgodności dogmatycznych, które by interkomunię uniemożliwiały. Również przełożony Palmera z Magdalen College w liście polecającym do metropolity o tę komunię prosi. Metropolita moskiewski Filaret (Drozdow), po przeczytaniu teologicznych pism Palmera, w których ten wyjaśnia rozumienie sakramentów, działania Ducha Świętego i innych spornych aspektów, stwierdza, że wszystko, co traktarianin napisał, jest:

„prawdziwe i godne uwagi, a stan utrzymujący się między dwoma Kościołami można bardziej określić mianem „ciszy” niż zerwania więzi. Jednak obecna praktyka w Kościele prawosławnym zakłada niedopuszczanie do komunii nikogo, kto nie podziela w całości tej samej wiary, dyscypliny i rytuałów religijnych. Cerkiew działa na podstawie domniemania prawdziwego podziału między Kościołami i zmiana tej zasady jest tylko w mocy Synodu" (UCR, 407).

Ta odpowiedź nie ostudziła zapału Palmera, który wciąż starał się zgłębić prawosławie i poznać Rosję. Coraz bardziej zadomawiał się też w Petersburgu, gdzie miał coraz większe grono znajomych. Zatrzymywał się w gościnie na wielu plebaniach, mieszkał też w domu dla studentów Akademii Duchownej (Spiritual Academy) oraz w pensjonatach prowadzonych przez Brytyjczyków (English lodging houses). Podczas jednego z takich pobytów w pensjonacie przy stole toczyły się rozmowy, które były skarbnicą wiedzy o rosyjskich zwyczajach, zabobonach, przywarach narodowych, a także charakteryzowały religijność Rosjan. Angielska gospodyni opowiadała:

„Rosjanie to bardzo religijny naród, lecz też bardzo przesądny. Brak im podstawowego wykształcenia i dobrze byłoby nauczyć ich czytać i pisać. Jeżeli chcą, by ich modlitwy były wysłuchane, po prostu zapalają świeczkę. Ich posty są bardzo surowe, co bardzo odbija się na ubogich, gdyż mięso jest tutaj tanie, 4 pensy za funt, a warzywa i ryby są w cenie. Ryba 5 pensów za funt. Nasza praczka na wyżywienie rodziny podczas postu 
musi wydać 80 kopiejek, zamiast 40, [...] rosyjscy służący wychodzą o 3 lub 4 nad ranem na poranną liturgię (w zimie wracając o 6-7). Poranna liturgia i nocne czuwania trwają po ok. 2 godziny i wielu Rosjan chodzi do Kościoła nie tylko w niedziele i święta, ale i w tygodniu" (UCR, 254).

Podejście do postu oraz gorliwość religijna prawosławnych to kwestie, które inspirują Anglika do zgłębiania mistycyzmu prawosławia. Jeżeli nawet zapalanie świeczki wydaje mu się zwyczajem pogańskim, to nocne pobudki przed ciężkim dniem pracy, by udać się do kościoła na modlitwę oraz surowe posty Rosjan napełniają go podziwem. Trudno, zdaniem autora Uwag, szukać tak gorliwych wyznawców Chrystusa wśród znanych mu anglikanów. Ósmego sierpnia 1840 roku Palmer zapisał w swoim dzienniku:

„Prawie codziennie jest tutaj jakieś święto kościelne. W ostatni wtorek, 6 sierpnia była wielka uroczystość, dzień, w którym święci się jabłka - „Winograd”- tak to się tu nazywa, a oznacza winogrona, ale z braku winorośli święci się tutaj jabłka. [...] Oni (Rosjanie A.P-P) nie będą ich jedli ani sprzedawali, dopóki ksiądz ich nie pobłogosławi. Kiedy budują dom, też nie zaczną, póki w środku nie zostanie umieszczony krzyż i pop nie poświeci tego miejsca. A 1-ego sierpnia i 6-ego stycznia święcą rzeki, czemu towarzyszy huczna procesja z wielka pompą” (UCR, 43).

Dwudziestego ósmego października Palmer zamieszkał z niejakim ojcem Fortunatowem (popem) i jego żoną, co pozwoliło mu na bardziej wnikliwe obserwacje codziennych zwyczajów prawosławnych duchownych oraz odbycie szeregu rozmów z ludźmi różnych stanów i wyznań, którzy - gdy rozniosła się wieść, że pop gości przybysza z Oksfordu - chętnie go odwiedzali. Jedni, by spróbować go nawrócić, inni, by usłyszeć jak żyje się w wielkim świecie, a jeszcze inni z najzwyklejszej ciekawości.

Miał zatem okazję poznawać nie tylko zwyczaje i zasady, którymi kierował się prawosławny kler i wierni, ale mógł też wziąć udział w liturgii, choć - mimo jego znów wzbudzonej nadziei i mocnej teologicznej argumentacji - nie było mowy o dopuszczeniu go do komunii. Pierwszy raz był świadkiem liturgii prawosławnej w zgromadzeniu w cerkwi kazańskiej i przyznał, że do tej pory nigdy nie było mu dane doświadczyć ,czegoś tak poruszającego i takiej jedności wspólnotowej w uwielbieniu Najwyższego" (UCR, 52). Swoje przeżycia opisuje w następujący sposób:

„Oddzielenie prezbiterium, bogato zdobiony ikonostas i surowa, nadprzyrodzona ekspresja pradawnych ikon sprawiły, że odczułem sacrum i nabożny podziw. Czyniono mnóstwo pobożnych gestów, kłaniania się i żegnania, całowania ikon, pokłonów i dotykania 
ziemi czołem (czasem wraz ze słyszalnym uderzeniem) i znów kłaniania się i żegnania się raz po raz, przez mężczyzn, młodych i starych, a także przez kobiety. A małe, smukłe, woskowe świece zakupione przy drzwiach były zapalane i ustawione na specjalnej podstawie. [...] Mój woźnica, ponieważ nie mógł wejść, bo musiał pilnować konia, przy drzwiach kościoła zwrócił mi kopiejkę z opłaty za przejazd »na zapalenie świecy«. W ten sposób jego modlitwa mogła być reprezentowana przed Bogiem przez płonąca świecę" (UCR, 40-41).

Łatwo zauważyć, że poza podkreślanym przez Palmera wrażeniem wielkiego splendoru - tak różnego od prostego, wręcz spartańskiego, wystroju kościołów anglikańskich - wynikającego z nabożnej czci oraz dbałości o schludność świątyni, wiele miejsca poświęca on zewnętrznym wyrazom pobożności okazywanym przez prawosławnych. Nie można jednak określić jego odczuć jako pozytywne. Odnosimy wrażenie, że pozostawał w stanie nabożnego zdumienia, wręcz niedowierzania, obserwując z lekką dozą nieufności i niechęci przesadne afiszowanie się prawosławnych ze swoją wiarą. Te zewnętrzne oznaki pobożności raziły Anglika, przyzwyczajonego do wyrażania uczuć w bardzo stonowany sposób i nigdy publicznie. Były bowiem całkowicie różne od angielskich norm zobowiązujących do nieokazywania głębokich uczuć na forum publicznym (UCR,41). Były momenty, w których wręcz odczuwał odrazę (repugnance) i biorąc pod uwagę takie reakcje, bardzo trafna wydaje się myśl Aleksego Chomiakowa, iż do definiowania i formułowania istoty Kościoła trzeba podchodzić od wewnątrz.

„Kościół jest przede wszystkim żywym organizmem, jednotą miłości, niewypowiedzianą wolnością, prawdą wiary, która nie może być zracjonalizowana. Osobie z zewnątrz trudno jest poznać i określić Kościół. Osiągają to poznanie tylko ci, którzy przebywają w nim i są jego żywymi członkami. W myśl tego stanowiska istota Kościoła (prawosławia) jest rozumiana na sposób apofatyczny, niedostępna spojrzeniu z zewnątrz - i to zarówno spojrzeniu katolika, jak i protestanta, ponieważ obaj znajdują się według Chomiakowa extra Ecclesiam"27.

Palmer mógł się szybko przekonać, że tym bardziej extra Ecclesiam pozostaje dla prawosławia kościół anglikański, który, oddając władzę nad Bożym ludem w ręce świeckich władców, jest prawdziwym zgorszeniem w oczach Cerkwi prawosławnej XIX wieku. Zgoła inne spojrzenie na tę kwestię ma prof. Natalia Suchowa, historyk Kościoła na Prawosławnym Uniwersytecie Humanistycznym św. Tichona w Moskwie, która tragedię ruchu oksfordzkiego widzi w tym, iż zakończył się on przej-

${ }^{27}$ L. Augustyn, Iwan Gagarin i kontrrewolucja religijna. Fragment dziejów kontrowersji..., [w:] Niedokończona dyskusja... Dziewiętnastowieczna polemika katolicko-prawosławna miedzy Iwanem Gagarinem SJ i Aleksym Chomiakowem, red. L. Augustyn, M. Kwaśnicka, Kraków, 2008, s. 24. 
ściem jego założycieli i wielu członków na katolicyzm ${ }^{28}$. Jednym z nich był właśnie William Palmer - niespełniony w ekumenicznych dążeniach, umarł w Rzymie pełen goryczy wobec swego kraju i drogi, którą obrał anglikanizm, nie pozostawiwszy mu innego wyboru jak konwersja na katolicyzm.

Analizując przyczyny klęski ekumenicznego przedsięwzięcia Palmera, można zdecydowanie stwierdzić, że główną był ogólny brak znajomości realiów historyczno-kulturowych oraz dogmatycznych. Wysuwanie takiego stwierdzenia pod adresem profesora - którego w wielu kręgach unikano z lęku przed jego wybitnym oczytaniem i wszechstronnym wykształceniem, z którym niewielu mogło konkurować - może wydać się niestosowne. Należy tu jednak podkreślić, że Uwagi w prawie każdym rozdziale wskazują na brak świadomości zdecydowanego i przez wieki ugruntowanego stanowiska Cerkwi w kwestii traktowania członków Kościoła katolickiego i anglikańskiego jako apostatów. Uczony z Oksfordu nie odważyłby się tak nazwać nawet protestantów, którzy zerwali całkowicie z Tradycją, ale postawa Cerkwi była tu jasna od stuleci. Palmer ulegał infantylnej projekcji połączonej z pewną pychą, myśląc, że właśnie on będzie tym prorokiem, posłańcem, pod siłą argumentów którego ugnie się Cerkiew prawosławna od wieków strzegąca Tradycji. Jak każdy ,prorok”, owładnięty poczuciem wyjątkowości własnej misji, Palmer nie wyciągnął wniosków z wysyłanych przez innych informacji i sygnałów.

Ives Congar, teolog dominikański, bardzo trafnie opisuje zachowania typowe dla człowieka, który dokonał pewnego osobistego odkrycia - jak Palmer - które z czasem przybiera dla niego siłę imperatywu:

„[...] ponieważ jest on samotny przez swe powołanie, grozi mu wyizolowanie się. Nieustraszony i owładnięty, wyzwala swe przesłanie w całej czystości, w jego absolucie i jego gwałtowności, nie dbając o wyważenie go lub zharmonizowanie z innymi elementami, które jednak również mają swoją prawdę ${ }^{29}$.

Drugim czynnikiem, który William Palmer ewidentnie zignorował, a może nie zdawał sobie w ogóle z niego sprawy, wybierając się w swoją podróż do Rosji, była kwestia uprzedzeń między prawosławiem i zachodnim chrześcijaństwem, zwłaszcza katolicyzmem. Autor Uwag nie władał językiem rosyjskim, więc mógł znać tylko dzieła literatury teologicznej przetłumaczone na angielski lub francuski. Choć przestudiował dogłębnie historię Kościoła rosyjskiego, to jednak nie dane mu było sięgnąc do tych prawd, które można odkrywać, sięgając do oryginalnej literatury kraju, który się odwiedza. Mówiąc przed wyjazdem o swoich obawach, Palmer nie

${ }^{28}$ Н.Ю. Сухова, У. Палмер в России..., ор. cit., s. 94.

${ }^{29}$ Y. Congar OP, Prawdziwa i fatszywa reforma w Kościele, Wydawnictwo Znak, Kraków 2001, s. 232. 
wspomina ani razu o nastawieniu Rosjan do łacinników. Wydaje się być zupełnie nieświadomy ugruntowanej w Rosji postawy nieufności - lub wręcz wrogości przekazywanej z pokolenia na pokolenie ${ }^{30}$.

Trzecią przyczyną fiaska tej misji mogła być zbytnia wiara w siłę dialektyki. Palmer, Brytyjczyk, wychowany w oksfordzkiej postawie szacunku wobec wykształcenia i retoryki, wierzący w przewagę solidnej, dogmatycznej argumentacji nad emocjami w dyskursie teologicznym, stanął wobec argumentów utrwalonych w świadomości prawosławnych od wieków ${ }^{31}$. Napotkał uprzedzenia, oparte na emocjach i motywacji religijnej, a on uparcie wierzył, iż jego gruntowne przygotowanie intelektualne wystarczy, by przekonać Cerkiew o możliwości interkomunii. Jego postawa idealnie wpisuje się w negatywny stereotyp łacinnika ugruntowany w kulturze rosyjskiej, a który Maksym Grek ujął tymi słowami:

„[...] we wszystkim oni błądzą, gdyż przede wszystkim kierują się zewnętrzną wiedzą dialektyczną, a nie wewnętrzną, darowaną przez Boga filozofią"’32.

Palmera zastanawia fakt, że Rosjanie bez trudu przyznają się do tego, że ich duchowieństwo słabo zna się na teologii i filozofii, i że rosyjscy duchowni tych czasów za myślicieli nie uchodzą. Andriej Murawjow, autor Historii Kościoła prawosławnego, stwierdza w rozmowie z nim, że „wiedza teologiczna wśród duchowieństwa jest nikła" (UCR, 169). W dyskusji z prawosławnymi hierarchami anglikanin wykazuje się erudycją, retoryką i biegłością teologiczną, która wprawia ich w szczerze okazywany podziw. Murawjow, żegnając Anglika i wiedząc o jego ostatecznym rozczarowaniu wynikiem rozmów, powtarza słowa metropolity moskiewskiego, które podzielają wszyscy znający Palmera duchowni, iż czerpali oni najwyższą przyjemność z dyskusji z nim i że kwestia, którą pragnął przedstawić jako wysłannik Kościoła anglokatolickiego nie mogła być przez nikogo innego lepiej reprezentowana (UCR, 552).

Rozgoryczenie Palmera jest w istocie olbrzymie, również z powodu braku zrozumienia faktycznych powodów odmowy interkomunii. Ten zachodni intelektualista z krwi i kości nie może się pogodzić z faktem, iż tak naprawdę spełnił wszystkie

${ }^{30} \mathrm{O}$ tych uprzedzeniach i ich źródłach por: А. Синайский, Отношение древнерусской и общества к ламинскому Западу (католичеству) X-XI бб., Санкт-Петербург 1899, ss. 25-26; U. Cierniak, Wiara $i$ władza - wokół sporu o katolicyzm i chrześcijańska Europę w dziewiętnastowiecznej myśli i literaturze rosyjskiej, Częstochowa 2013, s. 29-36.

${ }^{31} \mathrm{O}$ specyfice rosyjskiego myślenia o Tradycji, historii i religii pisze szeroko H. Kowalska, Kultura staroruska XI-XVI w. Tradycja i zmiana, Kraków, Wydawnictwo UJ, 1998, ss. 51-111.

${ }_{32}$ М. Грек, Слово похвальное к святым апостолам Петру и Павлу, в томже обличения и на латыньския три большия ереси, https://azbyka.ru/otechnik/Maksim_Grek/slovo_petru_i_pavlu/, thum. U. Cierniak [dostęp: 30.05.2019]. 
postawione mu przez prawosławnych warunki, a na koniec i tak dostał odpowiedź odmowną. Zapewniany wciąż przez interlokutorów o dobrej woli i życzliwości, nie posunął się ani o krok w misji zjednoczenia Kościoła. Podczas rozmowy z Wasylem Kutniewiczem (Koutnevich) zgodził się wyrecytować Credo nicejsko-konstantynopolitańskie i zapytany o uważane za główny punkt sporny filioque, wyjaśnił zebranym, że wierni katolicy również są zdania, iż sobory ekumeniczne nie powinny zmieniać słów Credo, a sam papież Leon III zgodził się, by pozostać przy greckiej wersji (UCR, 134). W liście wysłanym do swojego przełożonego w Magdalen College przed wyruszeniem w drogę powrotną Palmer daje upust goryczy, opisując największe swoje rozczarowania. Stwierdza, że anglikanizm jest zupełnie nieznany w Rosji oraz że rosyjskie duchowieństwo nie ma woli rozróżnienia między kluczowymi kwestiami wiary, niezbędnymi, by być członkiem Kościoła, a sprawami zupełnie drugorzędnymi, które są koniecznością tylko organizacyjną. Pisze w końcu, że do komunii nie zostanie nigdy dopuszczony, choć wyznał to samo Credo, gdyż rosyjscy hierarchowie kościelni boją się zgorszyć innych wiernych Kościoła wschodniego, np. litewskich unitów lub swoje niewykształcone chłopstwo (UCR, 360) ${ }^{33}$.

Trudno stwierdzić, dlaczego hierarchowie szukali tego typu wymówek, nie wyjaśniając Palmerowi swego stanowiska, mającego wielowiekową proweniencję. Przedstawia je na przykład Kallistos Ware, Anglik, wychowanek Magdalen College, profesor uniwersytetu oksfordzkiego i równocześnie jeden z najlepiej znanych teologów prawosławnych naszych czasów. Na pytanie o rozłam w Kościele odpowiada dobitnie, że nigdy do niego nie doszło. Twierdzi, że Kościół jest jeden - to święty Kościół prawosławny, niezmienny od czasów Chrystusa. To, że czasem schizmatycy lub heretycy odstępowali od Kościoła, nie ma wpływu na jego jedność ${ }^{34}$. Ware wskazuje na podstawową zasadę prawosławnych we wszystkich ich kontaktach ekumenicznych: ,zanim nastąpi powrót do jedności chrześcijan, musi dojść do pełnej zgodności w wierze”. Dążenia do jedności organizacyjnej bez jedności dogmatycznej są przedstawiane przez teologa jako wyrzucanie orzecha, a zachowywanie łupiny, gdyż:

„prawosławni nie chcą brać udziału w scenariuszu «zminimalizowanego» powrotu do jedności, który zadowalałby się dojściem do porozumienia w kilku kwestiach, a resztę pozostawiał osobistemu osądowi wiernych" ${ }^{35}$.

${ }^{33}$ Gdy w późniejszych latach powrócił do Rosji, mówiąc biegle po rosyjsku i mając grono serdecznych przyjaciół - jak pisze Newman we wstępie do Uwag - zdecydował się w końcu, by przejść na prawosławie. Warunkiem, jaki mu postawiono, było publiczne wyrzeczenie się wiary anglikańskiej, która według rozeznania Palmera była dogmatycznie tożsama z prawosławną, dlatego nie zdecydował się na ten krok i ostatecznie wrócił do Anglii, a później pojechał do Rzymu.

${ }^{34}$ K. Ware, Kościót prawosławny, Białystok, Bractwo Młodzieży Prawosławnej w Polsce, 2002, s. 343 .

35 Ibidem, ss. 344-345. 
Teolog ten wyjaśnia też, że z powyższego stanowiska wypływa konkretne następstwo: dopóki nie ma jedności w wierze, nie może istnieć jedność w sakramentach. Oczywiste jest zatem, że w istniejącej sytuacji prawosławie jasno wyklucza możliwość interkomunii ${ }^{36}$.

Widać wyraźny dysonans w definiowaniu ,jedności dogmatycznej” przez Cerkiew prawosławną i Kościół zachodni, znany od wieków i pogłębiający się jeszcze po uniach prawosławia z katolicyzmem, szczególnie florenckiej i brzeskiej ${ }^{37}$. Palmer wyruszył, wierząc w tę jedność i prawo do interkomunii, a powrócił jako człowiek pokonany. Postanowił jednak nauczyć się języka rosyjskiego, by móc badać teksty w oryginale i lepiej zrozumieć Rosję. Do Anglii przywiózł dzieło Andrieja Murawjowa: Historia Kościoła rosyjskiego, którego redakcji się podjął i obiecał wydanie w Oksfordzie. Zadanie to udało mu się wypełnić. W 1842 roku ujrzała światło dzienne ta precedensowa pozycja historyczna opisująca dzieje Kościoła rosyjskiego. Wielebny Blackmore, który przez długi czas pełnił funkcję kapelana w Rosji i biegle władał językiem rosyjskim, podjął się tłumaczenia na język angielski i opatrzył dzieło własnym wstępem. W przedmowie podziela on zdanie autora Uwag odnośnie konieczności propagowania wiedzy o różnicach dogmatycznych i teologicznych z nadzieją na zjednoczenie Kościoła:

„Podczas mojego dwudziestodwuletniego pobytu w tym kraju nie byłem obojętnym obserwatorem. Z racji mojej profesji i roli, jaką przyszło mi pełnić, w sposób naturalny myśli moje kierowały się ku sprawom religii. [...] W obecnych okolicznościach wiele ognisk uprzedzeń konspiruje, by dać członkom obu naszych wspólnot kościelnych jak najbardziej mylny i błędny obraz tych drugich. [...] Pozbycie się owej ignorancji i promowanie idei odnowy i interkomunii, tak bardzo pożądanej przez obie gałęzie Jednego Katolickiego Kościoła, ten obowiązek nałożony na nas przez Chrystusa - Głowę Kościoła, by nieustannie modlić się o jedność, która stanie się dla nas twierdzą mocy przeciwko wspólnym wrogom, ten obowiązek powinien być wypełniany przez każdego myślącego i przychylnego Kościołowi wiernego"38.

Chcąc podsumować na podstawie zgromadzonego materiału misję i rolę Williama Palmera w zbliżeniu ku sobie Cerkwi i Kościoła anglikańskiego oraz podtrzymaniu dialogu ekumenicznego między tymi dwoma „gałęziami” chrześcijaństwa,

${ }^{36}$ K. Ware, Kościót prawosławny, op. cit. , s. 345.

37 Por. A. Stradomski, Domus divisa. Studia nad literatura ruska w I Rzeczypospolitej, Kraków, Collegium Columbinum, 2002, ss. 9-90; J. Stradomski, Spory o ,wiare grecka” w dawnej Rzeczypospolitej, Kraków, scriptum, 2003, ss. 21-62, O. Halecki, Od unii florenckiej do unii brzeskiej, Lublin, Instytut Europy Środkowo-Wschodniej, 1995, t. 2, s. 24.

${ }_{38}$ A.N. Mouravieff, A History of the Church of Russia, tt. R.W. Blackmore, J.H. Parker, Rivingtons, London, Oxford 1842, ss. 5, 8. 
należy stwierdzić, że byłoby bardzo krzywdzące dla traktarianina oparcie się w tej ocenie na jego konkretnych dokonaniach ekumenicznych. $\mathrm{Z}$ całą pewnością można uznać, że Palmer zrobił wszystko, co było w jego mocy, by urzeczywistnić marzenie o jedności Kościołów, choć dialog z prawosławiem nie należał do łatwych. Gdy zdecydował się przyjąć religię prawosławną, również mu odmówiono ${ }^{39}$, podając wciąż takie same thumaczenia, a wśród nich to, że nie będzie mógł wrócić do Anglii, bo wywoła tam zgorszenie. Rosjanie trzymali się cały czas jednej linii argumentacji; ich własna odpowiedź odmowna i niechęć do podjęcia poważnych kroków ku zjednoczeniu była zawsze tłumaczona troską o zgorszenie jakiejś nacji lub grupy społecznej. W sytuacji, w jakiej się znalazł, William Palmer osiągnął jednak sukces, pozostając $\mathrm{w}$ bardzo dobrych relacjach $\mathrm{z}$ napotykanymi dostojnikami, wprawiając ich w podziw dla jego erudycji i dyplomacji oraz niespotykanej dialektyki. Kolejną, bezdyskusyjną zasługą, jaką oddał Cerkwi, jest przywiezienie do Oksfordu i doprowadzenie do publikacji wspomnianej już Historii Kościoła rosyjskiego Andrieja Murawjowa.

Pomimo wielu doznanych w Rosji rozczarowań Palmer po powrocie do ojczyzny nie ustawał w wysiłkach, by dalej pogłębiać swoją znajomość prawosławia i rosyjskiej historii. Efektem tych studiów była obszerna praca na temat patriarchy Nikona, słynnego inicjatora reformy ksiąg i obrzędów liturgicznych w siedemnastowiecznej Cerkwi rosyjskiej, zakończonej odejściem z niej staroobrzędowców. Praca nosiła tytuł Patriarcha $i$ car (The Patriarch and the Tsar) ${ }^{40}$. Wnikanie w ducha Rosji przybliżyło Palmera także do rosyjskich myślicieli XIX wieku, a szczególnie owocna była jego korespondencja z Aleksym Chomiakowem, z którym połączyła go głęboka przyjaźń. Gdy Palmer przetłumaczył wiersze napisane przez Chomiakowa na okoliczność tragicznej śmierci jego dzieci ${ }^{41}$, Rosjanin odpowiedział mu, iż bardzo ceni sobie tę pracę i niezwykle ważne były dla niego słowa wsparcia i współczucia, ale najważniejszym był fakt, że zostały wyrażone w taki sposób, że Chomiakow nie miał wątpliwości co do ich obopólnej jedności duchowych doznań i przekonań ${ }^{42}$. Rosyjski myśliciel napisał też, że gdyby Kościół prawosławny naprawdę był przekonany, że Palmer reprezentuje tylko samego siebie, a nie grupę wykształconych

39 A. Khomiakov, I. Kireevsky, On Spiritual Unity - A Slavophile Reader, Lindisfarne Books, New York, 1998, s. 141. Nikołaj Barsow podaje, że rzeczywistą przyczyną nieprzyjęcia Palmera na łono prawosławia był fakt, iż ten oficjalnie nie wyrzekł się anglikanizmu. Por. Н. Барсов, Пальмер, [w:] Энциклопедический словарь, red. Ф.А. Брокгауз, И.А., Ефрон, Санкт-Петербург, Типография И.А. Ефрона, 1897, t. XXа (44), s. 652.

${ }^{40}$ W. Palmer, The Patriarch and the Tsar, Londyn 1871-1876.

${ }^{41}$ Idem, Short Poeme and Hymnus, Oksford 1843.

${ }^{42}$ A. Chomiakow, First Letter to William Palmer, http://www.stjamesthejust.com/archives\%20(features)/(130)\%20Alexei\%20Khomiakov\%27s\%20First $\% 20$ Letter $\% 20$ to\%20William $\% 20$ Palmer\%20 \%5B1844\%5D.htm [dostęp:26.05.2019]. 
i wpływowych oksfordczyków, nie byłoby problemów z jego konwersją. Chomiakow ubolewał nad ewidentną zależnością Cerkwi od państwa i była ona dla niego jedną z przyczyn nieprzejednanego stanowiska Kościoła rosyjskiego, który bał się sprowadzić na siebie podejrzenie o wzbudzanie niezgody wśród obcokrajowców przez przyjmowanie ich przedstawicieli na łono Cerkwi. Korespondencja powyższa rzuca nowe światło na misję Palmera i pokazuje, że pobyt w Rosji nie był dla niego czasem straconym. Stał się raczej punktem zwrotnym w jego życiu duchowym. Dalszy rozwój wydarzeń, ciągły kontakt z Chomiakowem i studia własne nad liturgią, teologią i historią Kościoła pomogły angielskiemu ekumeniście i podróżnikowi wejść na wyższy poziom rozumienia istoty religii, jak i odmienności kulturowych Wschodu i Zachodu Europy.

Aby oddać pełny obraz misji Anglika w Rosji, lektura listów Chomiakowa do Palmera powinna być obligatoryjnie analizowana jako kontynuacja Uwag. Język, jakim posługują się przyjaciele i poziom dyskursu pokazuje, że oni już dawno tę wymarzoną jedność osiągnęli. To właśnie do Palmera pisze Rosjanin po śmierci ukochanej żony ze wstydem, iż czuje tylko ból, a powinien się cieszyć, że jest ona w rękach Boga. Z kolei u Chomiakowa odnajduje Palmer zrozumienie i wsparcie, gdy decyduje się w ślad za Johnem Newmanem przejść na katolicyzm. Palmer wierzy, że ci, którzy pragną być prawdziwymi patriotami i kosmopolitami powinni powtórzyć nie ustami, ale z głębi serca prośbę „o jedność wszystkich (о соединении всех)”43. Te słowa modlitwy z prawosławnej litanii od najmłodszych lat były bliskie Chomiakowowi, którego miłości do Cerkwi uczyła wyjątkowo pobożna matka. Z tymi słowami na ustach umierał 4 kwietnia 1879 roku w Rzymie William Palmer - rzymski katolik, konwertyta, którego marzenie o jedności Kościołów być może najpełniej się uobecniło w relacji duchowo-intelektualnej z Chomiakowem i badaniach teologicznych, które napędzane ich przyjaźnią, stały się cegiełkami w budowie więzi ekumenicznej obu Kościołów. W pośmiertnych wspomnieniach uznany został przez współczesnych sobie za najzdolniejszego i najlepszego absolwenta Magdalen College, który nie uznawał kompromisów i półśrodków ${ }^{44}$. Natomiast ze względu na towarzyszące mu aż do śmierci poczucie niespełnienia, spowodowane fiaskiem misji ekumenicznej do Rosji, koledzy przyznali mu miano „kościelnego Don Kichota”.

\footnotetext{
43 A. Chomiakow, First Letter to William Palmer, op. cit.

${ }^{44}$ R. Wheeler, Palmer's Pilgrimage: The Life of William Palmer of Magdalen, Berno, Peter Lang, 2006, s. 401.
} 


\section{Literatura}

Augustyn L., Iwan Gagarin i kontrrewolucja religijna. Fragment dziejów kontrowersji..., [w:] Niedokończona dyskusja... Dziewiętnastowieczna polemika katolicko-prawostawna miedzy Iwanem Gagarinem SJ i Aleksym Chomiakowem, red. L. Augustyn, M. Kwaśnicka, Kraków, 2008, ss. 9-32.

Birkbeck W.J., Birkbeck and The Russian Church, New York, The MacMillan Company, 1917, 372 ss.

Bułgakow S., Prawosławie, Formica, Warszawa 1992, 211 ss.

Byron R., Moskwa, „Zeszyty Literackie” 2012, nr 1, ss. 125-134.

Chomiakow A., First Letter to William Palmer, http://www.stjamesthejust.com/ archives\%20(features)/(130)\%20Alexei\%20Khomiakov\%27s\%20First $\% 20$ Letter\%20to\%20William\%20Palmer\%20\%5B1844\%5D.htm [dostęp:26.05.2019].

Chomiakov A., Kireevsky I., On Spiritual Unity - A Slavophile Reader, New York, Lindisfarne Books, 1998, 365 ss.

Cierniak U., ,,Dufny Lach” " , ,wierny Ross”. Rozważania o kompetencjach Polaków w sprawach rosyjskich, [w:] Kręgi kompetencji i perspektywy poznawcze, red. J. Goćkowski, P. Kisiel, Kraków, 1999, ss. 291-308.

Cierniak U., Religia z „krainy świętych cudów”, [w:] Bizancjum - Prawosławie Romantyzm. Tradycja wschodnia w kulturze XIX wieku, red. J. Ławski, K. Korotkich, 2004, ss. 43-53.

Cierniak U., Wiara i władza - wokót sporu o katolicyzm i chrześcijańska Europę $w$ dziewiętnastowiecznej myśli i literaturze rosyjskiej, Częstochowa 2013, 362 ss.

Congar Y., Prawdziwa i fatszywa reforma w Kościele, Kraków, Wydawnictwo Znak, 2001, 453 ss.

Inglot M., How the Jesuits Survived Their Suppression. The Society of Jesus in the Russian Empire, Philadelphia, Saint Joseph's University Press, 2015, 322 ss.

Inglot M., La Missione del Possevino nella Russia di Ivan il Terrible, [w:] Atti e Memorie, Academia Nazionale Virgiliana di Scienze Lettere e Arti, 2014, ss. 211-222.

Kalomiros A., Against False Union, Seattle, St. Nectarios Press, 1990, 170 ss.

Kowalska H., Kultura staroruska XI-XVI w. Tradycja i zmiana, Kraków, Wydawnictwo UJ, 1998, 306 ss.

de Lazari A., Wzajemne uprzedzenia Polaków i Rosjan, [w:] Katalog wzajemnych uprzedzeń Polaków i Rosjan, PISM, 2006, ss. 5-27.

Ljut'ko J., Two Oxford Scholars and Their Relationship with the Russian Church: William Palmer and Stephen Hatherley, https://www.academia.edu/3362426/ Two_Oxford_Scholars_and_their_relationship_with_the_Russian_Church_William_Palmer_and_Stephen_Hatherley [dostęp: 13.03.2019]. 
Mouravieff A.N., A History of the Church of Russia, tt. R. W. Blackmore, J.H. Parker; Rivingtons, London, Oxford 1842, 448 ss.

Musiewicz P., Ruch oksfordzki (1833-1845). Historia ruchu oksfordzkiego na tle nowożytnych relacji Państwo-Kościót w Anglii, Kraków, WAM, 2015, 284 ss.

Naumow A., Domus divisa. Studia nad literatura ruska w I Rzeczypospolitej, Kraków, Collegium Columbinum, 2002, 399 ss.

Obirek S., Antonio Possevino i jego misja do Moskwy, „Nasza Przeszłość” 1998, t. 89 , ss. 111-123.

Palmer W., Notes of a Visit to the Russian Church in the Years 1840-1841, red. J. Newman, London, Gilbert \& Rivington Ltd, 1882, 572 ss.

Pindus B., ,, Don Kichot w zniszczonym fraku”, czyli o heroizmie doktora Friedricha Haassa, „Kultura Słowian. Rocznik Komisji Kultury Słowian PAU”, t. XIV, 2018, s. 335-355.

Possevino A., Moscovia, Warszawa, Instytut Wydawniczy PAX, 1988, 279 ss.

Shore P., Jesuits in the Orthodox World, [w:] The [Oxford] Handbook of the Jesuits, red. I.G. Zupanov, ttps://www.oxfordhandbooks.com/view/10.1093/ oxfordhb/9780190639631.001.0001/oxfordhb-9780190639631-e-13 [dostęp: 06.05.2019].

Stradomski J., Spory o „wiare grecka” w dawnej Rzeczypospolitej, Kraków, scriptum, 2003, 341 ss.

Ware K., Kościót prawosławny, Białystok, Bractwo Młodzieży Prawosławnej w Polsce, 2002, 368 ss.

Wheeler R., Palmer's Pilgrimage: The Life of William Palmer of Magdalen, Berno, Peter Lang, 2006, 427 ss.

Барсов Н., Пальмер, [w:] Энциклопедический словарь, red. Ф.А. Брокгауз, И.А. Ефрон, Санкт-Петербург, Типография И.А. Ефрона, 1897, t. ХХа (44), ss. 652-653.

Грек М., Слово похвальное к святым апостолам Петру и Павлу, в томже обличения и на латыньския три большия ереси, https://azbyka.ru/otechnik/ Maksim_Grek/slovo_petru_i_pavlu/thum. U. Cierniak, [dostęp:30.05.2019].

Лабутина Т.Л., Англичане в допетровской России, Санкт-Петербург, Алетейя, 2011, 272 ss.

Синайский А., Отношение древнерусской церкви и общества клатинскому 3 паду (католичеству) $X-X V$ вв., Санкт-Петербург 1899, 162 ss.

Сухова Н. Ю, У. Палмер в России, https://www.academia.edu/8683694/_William_ Palmer_in_Russia [dostęp: 03.05.2019]. 


\section{References}

Augustyn L., Iwan Gagarin i kontrrewolucja religijna. Fragment dziejów kontrowersji...[Ivan Gagarin and Religious Counterrevolution. A Fragment of the History of Controversy], [in:] Niedokończona dyskusja... Dziewiętnastowieczna polemika katolicko-prawosławna miedzy Iwanem Gagarinem SJ i Aleksym Chomiakowem [Unfinished discussion... Nineteenth-century Catholic Orthodox Polemics between Ivan Gagarin SJ and Aleksy Khomiakov], Eds. L. Augustyn, M. Kwaśnicka, Cracow, 2008, pp. 9-32.

Barsov H., Pal'mer, Entsiklopedicheskii slovar'[Encyclopedic Dictionary], ed. F.A. Brokgauz, I.A. Efron, St. Petersburg, 1897, vol. XXa (44), pp. 652-653.

Birkbeck W.J., Birkbeck and The Russian Church, New York, The MacMillan Company, 1917, $372 \mathrm{pp}$.

Bułgakow S., Prawosławie, [The Orthodox Church], Warsaw, Formica, 1992, 211 pp. Byron R., Moskwa [Moscow], „Zeszyty Literackie” [Literary Notebooks] 2012, no. 1, pp. 125-135.

Cierniak U., ,Dufny Lach” $i$,, wierny Ross”. Rozważania o kompetencjach Polaków w sprawach rosyjskich ["Big-headed Lach" and "Faithfull Ross". Reflections on the Competences of Poles in Russian matters], [in:] Kreggi kompetencji i perspektywy poznawcze, [Circles of Competence and Cognitive Perspectives], Eds. J. Goćkowski, P. Kisiel, Cracow, 1999, pp. 291-308.

Cierniak U., Religia z „,krainy świętych cudów” [Religion from the "Land of Holy Miracles"], [in:] Bizancjum - Prawosławie - Romantyzm. Tradycja wschodnia w kulturze XIX wieku [Byzantium - Orthodoxy - Romanticism. Eastern Tradition in $19^{\text {th }}$ Century Culture], Eds. J. Lawski, K. Korotkich, 2004, pp. 43-53.

Cierniak U., Wiara $i$ władza - wokót sporu o katolicyzm i chrześcijańska Europę $w$ dziewiętnastowiecznej myśli i literaturze rosyjskiej [Faith and Power. Conflicts surrounding Catholicism and Christian Europe in the $19^{\text {th }}$ Century Russian Thought and Literature], Czestochowa 2013, 362 pp.

Congar Y., Prawdziwa i fatszywa reforma w Kościele [True and False Reform in the Church], Cracow, Wydawnictwo Znak, 2001, 453 pp.

Grek M., Slovo pokhval'noe k sviatym apostolam Petru i Pavlu, v tomzhe oblicheniia i na latyn 'skyia tri bol'shiia eresi [The Laudable Speech on St. Apostles Peter and Paul Feast and the Rebuke to the Three Latin heresies], transl. U. Cierniak, Available at: https://azbyka.ru/otechnik/Maksim_Grek/slovo_petru_i_pavlu/ [accessed: 30.05.2019].

Inglot M., How the Jesuits Survived Their Suppression. The Society of Jesus in the Russian Empire, Philadelphia, Saint Joseph's University Press, 2015, 322 pp. 
Inglot M., La Missione del Possevino nella Russia di Ivan il Terrible [The Mission of Possevino in Russia of Ivan the Terrible], [in:] "Atti e Memorie" [Acts and Memoirs], Academia Nazionale Virgiliana di Scienze Lettere e Arti, 2014, pp. 211-222.

Kalomiros A., Proclamation of the Holy Mountain, [in:] Against False Union, Seattle, St. Nectarios Press, 2000, 170 pp.

Khomiakov A., First Letter to William Palmer, Available at: http://www.stjamesthejust.com/archives $\% 20$ (features)/(130)\%20Alexei\%20Khomiakov\%27s\%20 First $\% 20$ Letter\%20to\%20William\%20Palmer\%20\%5B1844\%5D.htm [accessed: 26.05.2019].

Khomiakov A., Kireevsky I., On Spiritual Unity - A Slavophile Reader, New York, Lindisfarne Books, 1998, 365 pp.

Kowalska H., Kultura staroruska XI-XVI w. Tradycja i zmiana [Old Russian Culture in XI-XVI c. Tradition and Change], Cracow, WUJ, 1998, 306 pp.

Labutina T.L., Anglichane v dopetrovskoi Rossii [The English in Russia before Peter the Great], St. Petersburg, Alatea, 2011, 272 pp. de Lazari A., Wzajemne uprzedzenia Polaków i Rosjan [Mutual Prejudices of Poles and Russians], [in:] Katalog wzajemnych uprzedzeń Polaków i Rosjan [Catalogue of Mutual Prejudices of Poles and Russians], PISM, 2006, pp. 5-27.

Ljut'ko J., Two Oxford Scholars and Their Relationship with the Russian Church: William Palmer and Stephen Hatherley, Available at: https:/www.academia. edu/3362426/Two_Oxford_Scholars_and_their_relationship_with_the_Russian_ Church_William_Palmer_and_Stephen_Hatherley [accessed: 13.03.2019].

Mouravieff A.N., A History of the Church of Russia, trans. R.W. Blackmore, J.H. Parker; London, Oxford, Rivingtons, 1842, 448 pp.

Musiewicz P., Ruch oksfordzki (1833-1845). Historia ruchu oksfordzkiego na tle nowożytnych relacji Państwo-Kościót w Anglii [The Oxford Movement (18331845). The History of the Oxford Movement Against the Background of Modern State-Church Relations in England], WAM, Cracow, 2015, 284 pp.

Naumow A., Domus divisa. Studia nad literatura ruska w I Rzeczypospolitej [Domus divisa. Studies on Russian literature in the First Polish Republic], Cracow, Collegium Columbinum, 2002, 399 pp.

Obirek S., Antonio Possevino i jego misja do Moskwy [Antonio Possevino and His Mission to Muscovy], "Nasza Przeszłość" [Our Past] 1998, vol. 89, pp. 111-123. Palmer W., Notes of a Visit to the Russian Church in the Years 1840-1841, selected and arranged by Cardinal John Newman, London, Gilbert \& Rivington Ltd, 1882, $572 \mathrm{pp}$.

Pindus B., „Don Kichot w zniszczonym fraku”, czyli o heroizmie doktora Friedricha Haassa [„,Don Quixote in a Worn-out Tailcoat.” About the Heroism of Doc- 
tor Friedrich Haass], "Kultura Słowian. Rocznik Komisji Kultury Słowian PAU" [Proceedings of the Commission on the Culture of the Slavs PAU] 2018, vol. XIV, pp. $335-355$.

Possevino A., Moscovia [Moscow], Warsaw, PAX, 1988, 279 pp.

Shore P., Jesuits in the Orthodox World, [in:] The [Oxford] Handbook of the Jesuits, ed. I.G. Zupanov, Available at: https://www.oxfordhandbooks.com/view/10.1093/ oxfordhb/9780190639631.001.0001/oxfordhb-9780190639631-e-13 [accessed: 06.05.2019].

Sinaiskii A., Otnoshenie drevnorusskoi Cerkvi i obshchetstva k latinskomu Zapadu (katolichestvu) $X-X V$ вв. [The Attitude of Old Russian Society towards Catholic West in X-XV c.], St. Petersburg 1899, 162 pp.

Stradomski J., Spory o ,wiare grecka” w dawnej Rzeczypospolitej [Disputes about "Greek Faith" in the Polish-Lithuanian Commonwealth], Cracow, scriptum, 2003, $341 \mathrm{pp}$.

Sukhova N.Iu., U. Palmer v Rossii [W. Palmer in Russia], Available at: https://www. academia.edu/8683694/_William_Palmer_in_Russia [accessed: 03.05.2019].

Ware K., Kościót prawostawny [The Orthodox Church], Bialystok, Bractwo Młodzieży Prawosławnej w Polsce [The Brotherhood of Orthodox Youth in Poland], 2002, 368 pp.

Wheeler R., Palmer's Pilgrimage: The Life of William Palmer of Magdalen, Berno, Peter Lang, 2006, 427 pp. 